\title{
New shipbuilding dock at Belfast for Harland and Wolff Limited
}

\author{
W. G. N. GEDDES, K. R. STURROCK \& G. KINDER
}

\section{Messrs Geddes, Sturrock and Kinder}

This project started in rather dramatic fashion by a telephone enquiry, in mid-August 1967, to Harland and Wolff from the Esso Petroleum Company to the effect that they would like to build at Belfast two supertankers each of 250000 tons. That telephone call initiated the whole project.

93. Harland and Wolff promptly commissioned a feasibility study of a shipbuilding dock together with back-up steelworking shops. The report on the dock was submitted in September 1967 and a decision was taken almost immediately to proceed subject to cost, with the important proviso that concurrently with the construction of the dock the first ship would also be under construction and that the civil works must be so advanced as to allow a 'float out' by the end of November 1969 -about two years later.

94. Great credit is due to Harland and Wolff and to the Government authorities at Westminster and Stormont for their courageous and speedy decisions which allowed the contract to be placed with George Wimpey \& Co. Ltd at the beginning of 1968 .

95. The short time available before the contract starting date created problems in the design of the dry dock and alternative designs were prepared so that the differing conditions which were likely to be encountered could be accommodated. As the site investigation information developed and the job opened up, the designs were crystalized to the form finally adopted and dealt with in the Paper. The logistics of the construction of this, the world's largest shipbuilding dock, the associated crane tracks and new steelworking facilities are worth repeating. The excavation and imported filling totalled nearly $400000 \mathrm{~m}^{3}$, there were $200000 \mathrm{~m}^{3}$ of concrete placed and approximately 7000 piles driven. It must also be emphasized that during the construction period shipbuilding had to continue on the existing berths and the construction of the first tanker was scheduled to start in the dock in the spring of 1969. To meet this strict schedule every item of construction was carefully examined to ensure simplicity of detail and the maximum amount of repetition possible. Particular care was taken to evolve dock wall and floor designs which could be built with the minimum number of concrete pours. In the case of the dock walls, these were detailed so that they could be built using only three main pours, i.e. the base which also forms part of the floor, the main stem which was placed in one lift of ten metres in height, the cope which projects inwards from the main stem and finally a small fourth pour to complete the small parapet wall. About $200 \mathrm{~m}^{3}$ of concrete were required for each of the floor bays and the wall bases, and $250 \mathrm{~m}^{3}$ were required for the wall stem panels. A wall stem shutter was provided for each side of the dock and the rate of progress was slightly better than one panel per week when averaged throughout the whole concreting period and each shutter was re-used about 55 times. Accuracy of construction was essential on the crane tracks and to support the high wheel loadings, particularly those from the goliath crane, a specially formulated epoxy resin grout was used below the crane rail sole plates.

96. In order to achieve completion within the two-year period stipulated, 24 hour working under floodlights was instituted early on, and a $30 \mathrm{~m}$ length of dock had to be completed each month to keep pace with the ship construction. Strict co-ordination of crane track construction was necessary to allow for the programmed erection of the goliath crane and the other auxilliary cranes. Throughout the construction

Paper published: Proc. Instn Civ. Engrs, 1972, 51, Jan., 17-47. 
period the normal and increased shipyard production had to be kept going, and both the design and construction teams became deeply involved in the many problems concerned with the building of the big ship around which the whole exercise revolved. Complete collaboration was enjoyed between the shipyard, the contractors and the designers in the overall planning and in the detailed construction programme.

97. It is with satisfaction and appreciation of the British construction industry that we can record that the programme was met, that the tender and estimated costs were not exceeded and the final costs were below those quoted in the Paper. This at a time when the province was undergoing many other problems was no mean achievement and illustrates what can be done by co-operation and a will to succeed.

98. Possibly the British shipbuilding industry does not always receive the credit to which it is due, but acknowledgment must be made of the courageous and farsighted decisions made by Harland and Wolff in an endeavour to keep in the forefront of world shipbuilding.

Mr R. E. J. Worth, Manager, Civil Engineering Design and Construction Planning Department, George Wimpey \& Co. Ltd

I endorse the Authors' comments on co-operation by all concerned, which was of a degree unprecedented in my experience. The Contract was let on a schedule of rates basis and an approximate bill of quantities with outline drawings. As a result, most of the details were being designed while operations were being planned and work started. During most of the detailed design period the Consultants were constantly in touch with Wimpey's engineers as soon as sketch details were produced to obtain suggestions for simplifying construction. This close contact played a considerable part in completing what many people thought was an impossibly short programme.

100. I should like to thank the Clients for their unstinted efforts to make Wimpey's task as unhindered as possible by the normal working of the shipyard and for their unfailing good humour.

101. The tender programme was based on a dock $397 \mathrm{~m}$ long but after the letting of the Contract this was increased to $550 \mathrm{~m}$ and still completed in the same contract time.

102. For the shorter dock it had been planned to place all the excavated material in the length of the Musgrave Channel south of the headwall, but all this excavation, and more, had to be taken off site and placed in bunded reclamation.

103. The suggestion that the Client should erect some of his permanent floodlighting early in the job made a substantial contribution to the efficiency achieved on the night shifts.

104. The nature of material in the bed of the channel was unknown until dewatering had taken place and 3-4 ft of almost liquid mud had been cleared. It was only then, some $4 \frac{1}{2}$ months after the letting of the Contract, that a borehole programme could be put in hand.

105. Excavation and rock filling were not the straightforward operations which had been anticipated, since the formation levels were varied as the borehole results for different areas became available. The formation was intersected by the trenches for the underfloor drains and the three intermediate sills which were introduced after the letting of the Contract. These trenches constituted a considerable obstruction to traffic, which grew rapidly during the job.

106. The originally planned pattern of construction was to concentrate initially on the five centre bays of floor using a 15 ton tower crane travelling on the centre bay. This left two bays on either side for 10 ton derricks to travel on the rockfill between these centre bays and the wall bases. These derricks were to be used to concrete the walls and the two outer rows of 'hit' floor bays, leaving the tower crane following to fill in the 'miss' bays.

107. Unfortunately, when the decision to lengthen the dock was made, the headwall, instead of being a pitched slope, became the heavy sheet-piled and rock-anchored 
wall described in the Paper. This required that a bank should be left against the piling for support until the rather protracted anchoring operation was completed. This meant that the three southern wall bays on each side had to be left until the bank could be excavated, which in turn entailed leaving out the concreting of all the derrick track bays to maintain access to these three wall bays. The completion of these bays was a messy and time-consuming operation involving considerable hand work, and in the south-west corner conditions were wetter than usual and the headwall piles had reached refusal above their designated penetration.

108. When this work was completed, to catch up on lost time and because the derricks were better suited to pile driving, they were moved to the north and concentrated upon driving the bearing piles under the wall bases. The tower crane was moved from the centre bay to an outer bay and another tower crane was introduced on the opposite side. These cranes then did all the concreting of floors and walls.

109. At the beginning of the Contract there was a one-week restriction on placing adjacent floor bays but this was soon reduced to three days, and the tower cranes were allowed to travel over a three day old bay but not to lift from such positions.

110. A delay of one week between placing adjacent wall bays was specified but this was of no consequence since it proved impractical to do other than concrete the walls 'hit and miss'. This was mainly because the congestion of vertical steel at the ends of the bays left no room for the fairly substantial walings holding the stopend shutter.

111. When the detailed design of the wall was completed, a layer of reinforcement was found necessary on the front face of the wall. This made concrete placing in the wall floor bays more difficult as smaller skips had to be used between the upstanding layers of reinforcement, and a pneumatic placer had to be introduced to concrete the heel of the wall.

112. The extra reinforcement on the front face and the bunching of reinforcement on the back face with $70 \mathrm{~mm}$ clear between bars made shutter cleaning more difficult and prevented the use of $75 \mathrm{~mm}$ cones for tying the forms, and she-bolts were used instead. A further delaying effect was that the front kicker could not be placed before the back steel was in because the projecting pile heads clashed with the radius bars and the front steel could not be fixed before the kicker was in position.

113. At the Tender stage, precast concrete piles for the crane tracks were specified and bored piles for the sections near the Client's computer house. Steel $\mathrm{H}$ piles were substituted for precast concrete piles because they would cause less ground displacement which might have affected the marginal stability of the side slopes, they would more readily penetrate layers of cobbles and the rock and because the driving would be faster.

114. Regarding bored piles, no sub-contractor would quote because of the subartesian water pressure in the rock. By taking records of ground vibrations at various distances from an $\mathrm{H}$ pile during driving, and other records of vibrations in the computer house under normal use, it was possible to show that the vibratory accelerations because of pile driving were only a fraction of those induced by the computer operators walking on the floor. Similar vibrograph records taken on the side slopes during wall foundation pile driving showed lesser effects than those caused by traffic on the road above the slope and by traffic on the dock floor. In spite of these latter results, a restriction was maintained on the minimum distance of pile driving from wall base concreting operations.

115. The production of concrete was a major operation and was programmed to have a quick build-up to $4300 \mathrm{~m}^{3} /$ week. In fact the build up was a little slower than planned, and the $4300 \mathrm{~m}^{3} /$ week was held for six months and then stepped up to 5500 $\mathrm{m}^{3} /$ week for three months. These figures are for the dock alone and not for any ancillary works. To be certain of achieving these outputs, it was decided to install plant with a maximum capacity of $7300 \mathrm{~m}^{3} /$ week. 
116. During the peak concreting period, the main water supply to Belfast was sabotaged and to overcome the shortage, permission was given to use the water from the deep wells, which had an average salinity of only 150 parts per 100000 . This was used for a two-week period until normal supplies were again available.

117. Regarding the sand runs, a similar wall, albeit only $20 \mathrm{ft}$ high, has been poured with no such effects but there pumped concrete was used which required a substantially higher cement content. Why was the inner face sloping and the outer face vertical?

118. In order to fix accurately the holding-down bolts of the goliath crane track during concreting of the beam, the 20 in. wide sole-plates were used as templates. The bolts were ordered 6 in. longer than necessary so that the sole-plate could be raised well above the top of the beams during concreting to give access for finishing the surface of the beams.

119. The major problems in the job were organizational rather than technical and tribute should be paid to the Project Manager, Mr Bedell, for the timely completion of the Contract. To help achieve this result, some 20000 manhours were spent on detailed planning in Wimpey's head office, apart from the work of the engineers on site.

120. When so much trouble was taken to drain the underside of the floor to eliminate water pressure, and when the inflow through the side slopes was so small and the walls were backfilled with granular material, why was no attempt made to do the comparatively simple operation of draining the back of the wall, which surely would have removed a major part of the horizontal loading?

\section{Mr R. Sweetnam, Deputy Chief Engineer, Belfast Harbour Commissioners}

Belfast is the largest port in Ireland. Virtually every inch of its land area of 700 ha has been reclaimed from the sea. Despite its area, an aerial view of the harbour shows how the 5 ha floor of the building dock dominates the panorama and dwarfs all the earlier shipbuilding facilities.

122. Shipbuilding has been done at Belfast for many centuries, but the foundation of the shipbuilding industry can be attributed to Mr William Ritchie, who constructed a shipyard on the site of the present Harbour Office in 1791 and launched his first ship, the Hibernia, of 300 tons, in the same year.

123. The origins of the Queen's Island works of Messrs Harland and Wolff date from 1851, when Mr Kirwan opened a new yard on the island site formed by the then recently completed straightening of the channel of the River Lagan.

124. From the early nineteenth century the Belfast Harbour Commissioners and their predecessors, the Ballast Board, encouraged the construction and repair of ships by the provision of dry docks and fitting out wharves. Six dry docks have been provided by the Board and their sizes and the intervals between their construction reflect the pattern of growth in ships' sizes.

125. The first, opened in 1800 beside Ritchie's Yard, could accommodate ships of 300 tons; the second, third and fourth docks of progressively larger capacity were opened in 1826, 1867 and 1889 . The fifth, the Thompson Dry Dock, was opened in 1911 and was the largest in the world, holding such famous ships as the Titanic and Olympic. Now, limited by its $30 \mathrm{~m}$ entrance width, it can take vessels of 40000 tons dwt. The latest, the Belfast Dry Dock, which was planned in 1965 to be one of the largest in Europe and capable of taking the largest vessels envisaged, can accommodate vessels of 200000 tons dwt. That two years later, in 1967, Messrs Harland and Wolff should plan a building dock capable of accommodating ships of a million tons deadweight, is an indication of the rapid rate of growth in ship sizes and the vision of the shipbuilding industry in Belfast.

126. When the Belfast Harbour Commissioners were approached regarding the project of the shipbuilding dock they welcomed the opportunity of further improvement in the port's facilities and readily agreed to making the site, which contained five 
major fitting out berths and a steel delivery wharf, available. The ready excavated basin thus provided and the existing roads must have contributed substantially to the feasibility of constructing the dock to the exacting schedule laid down.

127. The Commissioners also immediately investigated the problems which would arise in getting vessels of this large size to sea and re-planned the proposed development of new quays at the harbour airport site to ensure that adequate channel widths would be available to meet the requirements of the full potential of the dock.

128. The construction of this shipbuilding dock and of the Belfast Dry Dock with its repair facilities has ensured that Belfast is well placed to maintain its eminence in the shipbuilding and ship repairing centres of the world.

\section{Mr J. G. Berry, Bertlin \& Partners}

I should like to refer to the question of cement content. Table 3.5 of the Draft Unified Concrete Code gives the recommendations as in Table 3 for reinforced concrete in external conditions.

130. The cement contents recommended are far higher than those adopted in the past and I am interested to see from the Paper that a cement content of $285 \mathrm{~kg} / \mathrm{m}^{3}$ was used at Belfast. Could the Authors comment on the reasons for adopting this?

131. Another area where practice often departs from theory is on whether to design the reinforced concrete work in a dock to the liquid-retaining code of practice. It is possible to compromise by limiting the reinforcement stresses although this does not give a no-crack condition. The Paper refers to the use of high tensile reinforcement from which might be inferred that stress limitation was not adopted. I would be glad if the Authors could explain the assumptions on which the reinforced concrete design was based.

132. On the subject of sand runs $I$ have had a similar experience in connexion with a sea wall. This was a contract where the cement content was kept low by means of a plastercizer and on the curved face of the wall there was difficulty with sand runs. It is likely that the low cement content was the cause.

133. I am interested to learn that bituminous painted joints were used between bays and not expansion joints. It is often argued that the initial shrinkage of a bay is greater than the subsequent thermal expansion but an occasional expansion joint is often provided as an insurance. I should be glad to know whether the Authors considered this.

134. There is sometimes trouble with bituminous paint weeping from a joint and spoiling the appearance. Did this happen at Belfast?

135. The reference to driving sheet piling into the body of a rockfill cofferdam is rather ironic. In other papers on dock construction in Bombay ${ }^{3,4}$ a cofferdam was constructed on similar lines but with an impermeable silt and clay core. There was some piping across the core and steel sheet piling was driven down as a remedy. In

Table 3

\begin{tabular}{l|c}
\hline & $\begin{array}{c}\text { Cement content, } \\
\mathrm{kg} / \mathrm{m}^{3}\end{array}$ \\
\hline $\begin{array}{l}\text { Sheltered against direct rain and against freezing while saturated } \\
\text { with water }\end{array}$ & 280 \\
Buried concrete \\
Exposed to alternate wetting and drying and to freezing while \\
wet \\
Exposed to sea water
\end{tabular}


this case the use of sheet piling was not a success and although the leakage was reduced it was not eliminated. I should be glad to know whether the grading of the rock used for the Belfast cofferdam was such that it was possible to drive sheet piles through it.

\section{Mr M. J. Tomlinson, Wimpey Laboratories Ltd}

The matters of most concern to the Contractors and at the time of the design to the Consulting Engineers, were whether or not the slopes of the Musgrave Channel, after dewatering and after excavation, would be stable sufficiently long for the dock walls to be constructed.

137. There were three problems in the stability analysis: the stability of the slopes of the Musgrave Channel after pumping down, the stability after re-grading the slopes to a uniform profile, and the stability after cutting back the slopes to a vertical face to provide working room for constructing the base for the wall.

138. Adequate measures were taken to control the stability after pumping down by the provision of the rockfill toe to the slopes, but at some stage the rockfill toe had to be removed, the slopes had to be regraded to a steeper slope, and then they had to be cut vertically to construct the wall foundation. In this respect the bearing piles for the wall foundation were a great help in reducing the depth of the excavation. These piles provided a means of strutting back sheet piling used to retain the slips which took place.

139. The stability problem was solely one of time-scale. An analysis showed that in the short term the slopes would be stable. Although the drainage would improve the stability of the upper part of the slope, with time there was a loss of stability because of softening of the Boulder Clay at the toe of the slope consequent on removal of the overburden pressure. This reduced the stability with time. At the planning stage it had to be decided whether the walls could be constructed with a vertical face, or whether sheet piling was needed at the initial stage of construction. To provide sheet piling on both sides of the wall foundation on each side of the dock would have added considerably to the time and cost of the temporary works, so the calculated risk was taken with regard to slipping. In my view it was permissible to take this risk, because there was the escape route, i.e. the slips could be dealt with by sheet piling and either by tying back the sheet piles to the crane rail piling at the back of the slope or in the case of limited slipping by strutting them to the bearing piles of the dock.

140. There was some slipping in the Boulder Clay. At one point the line of the slip coincided with the slip circle, which had given the least safety factor in the analysis. Seepage from the water from the sand layer found its way into cracks in the Boulder Clay and contributed to the instability of this particular part. The worst conditions of slipping were in the Boulder Clay, where the timber jetties had been driven, and where it might have been expected to be stable. I formed the tentative view that the instability in this area was because of the cracking of the Boulder Clay, caused by driving the timber piles which cracked the clay and allowed water to seep in.

\section{Mr D. D. Land, Edmund Nuttall Ltd}

There is insufficient practical detail in the Paper, and a job of this size would have justified a second construction paper by the Contractors.

142. Regarding the side wall shutter, the Authors cannot account for the sand runs. High pours like this are becoming common, and in work which is prominently exposed such disfigurement could be serious. Can the Authors give a drawing of the shutter and details of the concrete mix and pouring rate so that people can draw their own conclusions? On the Greenock Dry Dock the side walls were poured in a $25 \mathrm{ft}$ high shutter and there was no trouble. That shutter was faced with ply on a steel frame and there was a slight batter to the wall, whereas here the shutter was steel-faced with a more pronounced batter. 
143. Describing the anchorage to the head wall, the Paper states that the load applied to the rock anchors before excavation was $75 \%$ of the final working load and that after excavation the final working load was applied. Nowadays anchored sheet piling is common, and the more information that is available the better, particularly in very soft, bad ground. At Greenock, where anchored sheet piling was used in the temporary works, there was a substantial loss of initial load within three or four days. Was there a significant initial loss here due, perhaps, to compression of the sleech behind the piling, and was there any significant variation between the individual anchors after the first few days? Did the load on the anchors increase during excavation? The material in front of the piling may have been exerting a live load which would come off during excavation and thereby increase the anchor load.

144. The two small cofferdams at the entrance are interesting because they were built in the slope of the channel in bad ground conditions. One of them involved anchored piling. Could the Authors supply a drawing of at least this cofferdam, and give details of the variation of the anchor load during the construction stages?

145. Machined iron castings were used for the gate meeting faces. The Paper says that 'extreme accuracy was required' in setting. Does that mean greater than is normally specified for dock entrances? If so, what was the tolerance and were the normal methods of setting these stones adequate? Why is great accuracy required to seat gates which cannot be built in shipyards to the same accuracy that contractors normally obtain with meeting faces?

146. There was a lot of pile driving. What sort of equipment was used to drive the piles?

Mr D. B. Kimber, formerly Harland and Wolff Ltd, now Chemical Industries Association Ltd

There is an analogy between the way in which this large development project at Belfast was done and some of the principles recently enunciated by Lord Rothschild for the conduct of Government-sponsored Research and Development. Rothschild postulates the customer-contractor relationship whereby the customer says what he wants, the contractor does it if he can, and the customer pays. He also notes that at the outset the customer may not know exactly how to define every aspect of his objective, the contract being developed through a dialogue at several levels between the customer and the contractor. Precisely this was done at Belfast, the shipyard being the customer and the consulting civil engineers, in this context, the research and development contractor. It was even possible to identify the individuals who were, in Rothschild terminology, the chief scientist and controller of research and development in the 'customer's' and 'contractor's' organizations respectively. It worked out well, perhaps-and not entirely fortuitously-because the main dialogue was between a small group whose members had been conducting similar dialogues in other places for several years and who knew each other's minds, with their particular strengths and weaknesses. Each person played his part in problem-solving swiftly and decisively: almost every detail was considered, discussed, and settled as it arose and where outside authorities were concerned in these decisions-notably the Belfast Harbour Commissioners-it was fortunate that they were prepared to take, with equal alacrity, what were, for them also, quite far-reaching and fundamental decisions.

148. Once Harland and Wolff Limited, stimulated by overtures from a major oil company, had decided to enter the $250000 \mathrm{t} d w t$ and over shipbuilding 'club', the uniquely favourable topography of the Queen's Island site pointed immediately to a solution based on a building dock although other possibilities based on enlarging an existing slipway were examined. Although some large vessels, in excess of $250000 \mathrm{t} d w \mathrm{t}$, continue to be launched successfully from slipways, in certain circumstances local stresses induced in the bottom structure of these huge hulls can be high 
during the transfer from slipway to water. Any resulting structural deformations may be extensive and are costly to put right.

149. Another, and more obvious, principal advantage of building in a dock is that the accurate placement of large weldments (of up to 800 tons at Belfast) is much easier when working to a horizontal datum than to the $1: 25$ declivity of a slipway. Ideally, the dock bottom would be constructed as a giant engineer's surface table, although in practice it cannot be quite plane if ponding of rain water is to be avoided. The profile of the dock bottom for drainage purposes was probably the only feature which, for some reason, escaped the iconoclastic scrutinies which preceded the determination of every other detail and hindsight now suggests that a rather different solution would have been more compatible with the special ship support system adopted. However, this is a minor criticism.

150. Referring to $\$ 145$, shipbuilders are well aware that the inch is now divided into 25.4 parts called millimetres and are quite able to work to $\pm 1 \mathrm{~mm}$ (instead of $\pm 1 / 32$ in.) where necessary. The gates of the big repairs docks at Greenock and Belfast, constructed in shipyards with which I was associated, were as 'tight as a drum' from the day they were installed - sufficiently eloquent testimony to the accurate work of both shipbuilder and civil engineer concerned!

Mr J. W. Baxter, G. Maunsell \& Partners

The under-floor drain blocks were lifted by means of steel reinforcement projecting from the precast units. On a job with which I have been concerned some blocks weighing 40 tons were similarly supported using four mild steel lifting loops made from reinforcement. The contractor used balancing beams so that the load was evenly distributed and the stress in the bars was less than 3 ton/sq. in. The first unit made was lifted successfully twice but the third time one of the bars broke and the unit fell. Luckily no-one was underneath. Since this accident, which was caused by a crack in the bar, my firm has never adopted this means of lifting because it is dangerous even when working to low stresses.

Mr M. Agar, Mersey Docks and Harbour Co.

Another dry dock was built at the same time about half a mile away. Was any research done to see if there was an advantage in combining the two docks in any way? The pumping and electrical arrangements might perhaps have been combined.

153. I consider the programming of the work and co-ordination with the shipbuilding in the dock to be something to be admired.

\section{Mr J. Williams, Director of Engineering. National Ports Council}

In order to build these monster ships the shipbuilders require a dock with a depth over the sill at mean high water springs of $8.38 \mathrm{~m}$. My interest is in the facilities for these ships when they are in service. To pass such vessels through a lock entrance requires a depth of three times that figure, and the cost of a lock will, I think, be three times the cost of this dock. In spite of the undoubted co-operation and imagination in the concept and construction of this dock, did the fact that it is in effect a shallow dock contribute to the marvellous progress of the scheme?

Mr J. C. Mardell, Joint Planning Team, Department of the Environment, HM Naval Base, Portsmouth

From a site where over 6000 steel $\mathrm{H}$ piles were used it would be valuable to have some analysis of the pile test records. Could the Authors give this, if available, and their conclusions from the extensive use of this type of pile? 
Mr W. R. Cox, Chief Engineer (Structures), Sir William Arrol Branch, Crane and Bridge Division, Clarke Chapman-John Thompson Ltd

As the main dock gate is of unusually large span it may be of interest to add to the information given in the Paper, at the same time highlighting some of the problems encountered during the design of the caisson gate.

157. The gate weighs 1476 tons including 200 tons of roadway deck and 92 tons of permanent water ballast. A further 500 tons of water ballast is pumped into the scuttling chambers during stepping. The minimum preponderance is 100 tons and the maximum preponderance is 2000 tons. This latter figure includes 336 tons of live load spread over the full length of the roadway.

158. In the initial stages of design only one skirt placed centrally below the base girder was envisaged. As the gate was required to be capable of sealing on either face it was necessary to place the bottom sill girder centrally also and this had the effect of substantially increasing the upthrust on the gate when the dock was dewatered, because of the water pressure acting on the underside of the half sill girder between the skirt and the sealing face. The adoption of two skirts reduced this uplift to a minimum and in so doing reduced the amount of water ballast required to scuttle the gate and maintain the necessary preponderance. It also allowed an end width of gate to be chosen such that excessive thicknesses of deck plate were not necessary to take the high shears occurring at the gate ends. The sealing face arrangement was also simplified, allowing vertical jambs where otherwise they may have had to be inclined.

159. In order to cater for the possibility of a ship colliding with the gate a nominal impact force of 50 tons acting at any position throughout the length of the gate was taken into account.

160. One of the major problems in a gate of this type with a large length to height ratio and incorporating a torsionally stiff box girder is to ensure that under maximum water level conditions the lower corners do not deflect away from the meeting face thus leaving gaps through which leakage will occur. Several changes in the general shape of the gate were made before the final analysis indicated that the corners would not pull away. The relatively flexible skirt below the box girder was one of the factors which helped in the solving of this problem.

161. The roadway deck is supported generally on columns which are pinned top and bottom and on sliding bearings at the ends. This allows the gate structure to deflect under load without transferring load to the roadway deck. This lateral independence of the roadway deck, which is continuous for the full length of the gate except for the small removable portions at the ends, means that it does not have to cater for such lateral loading in combination with the heavy truck vertical loads, nor does it show to the road users the deflected form of the gate. The deck is held transversely near its ends and longitudinally near the centre of the gate to take wind and traction forces.

162. For the towing operation from Glasgow to Belfast it was considered advisable to seal off completely the open areas between the roadway deck and the top of the gate, the flooding trunks and the scupper pipes being sealed with blank covers. This was to avoid the trough portion of the gate above the box girder filling with water from rain or excessive wave action as this could have resulted in the gate becoming more difficult to handle and eventually unstable. The gaps were scaled by close timber boarding covered by polythene sheeting.

\section{Mr A. Craigmile, NE of Scotland Water Board}

In $\$ 39$, the problem of sand runs on the inclined face of the wall stem was described. In a recent reservoir contract, a similar problem occurred on the surface of the mass walls, and various measures including variations to the concrete mix, spading concrete adjacent to the shutter and alterations to the shutter supports were tried and 
found to be ineffective. I would be interested in methods used to try to eliminate the problem.

\section{Mr J. L. Ashford, Civil Design and Planning Department, G. Wimpey \& Co. Ltd}

The temporary works for the construction of the two roundheads posed unusual problems. The site investigation showed that a bed of clay containing boulders and lenses of wet sand lay between the weak Belfast sleech and the bedrock. Thus the classical hazards of excavating boulder clay within sheet piling were combined with the inherent instability of a side slope location and, in addition, on the eastern side the structure was to be founded on bedrock so there was little chance that toe support of sheet piles would be achieved.

165. On the west side reasonable penetration of sheet piles below foundation level seemed probable, and as the structure was almost entirely mass concrete, the solution selected was to construct in cells. The intention was to limit any particular area of instability to a small proportion of the whole, and to maximize use of the deadweight of parts of the structure as they were built to support excavations for the remainder.

166. Sheet piles were driven around the perimeter of the roundhead (approximately $27 \mathrm{~m} \times 15 \mathrm{~m}$ ) and the area was divided into five cells by four internal diaphragms. It was necessary to strike a balance between achieving certain fixity in the piles by maximizing penetration and minimizing obstruction to water flow from inside the cofferdam to the dewatering wells $(\$ 24)$ by leaving maximum space between the pile toes and bedrock. In the areas of highest stress the balance was struck by taking half the piles to the point of calculated fixity and half to bedrock. Spoil was placed on the east side of the cofferdam to ensure stability of the structure as a whole in the early stages.

167. Cells 1, 3 and 5 were in turn excavated and concreted to a level $3 \mathrm{~m}$ below the cope. The spoil on the eastern side was then removed and sheet piles on the north, east and south sides and the diaphragms were extracted.

168. Cells 2 and 4 were then excavated, with the pile curtain on the west side supported by walings spanning between and bearing against the concrete in the primary cells. Having concreted cells 2 and 4 the remaining sheet piling was withdrawn and the top $3 \mathrm{~m}$ of the roundhead was concreted in two lifts over the whole area.

169. This method could not be applied to the east roundhead because this structure housed the pumping equipment and was too complex to be built within cells. Various alternatives were considered but the final decision was to adopt the principle used in the design of the dock headwall and support sheet piles with raking rock anchors.

170. The temporary sheet pile wall had to be the same height as the head wall, but since time and cost precluded the use of high modulus composite piling, up to three levels of anchors were installed, using standard Larssen No. 4 sheet piles. The curtain of piles on the eastern side was supported by anchors of 180 tons working load which were installed at levels $+1.2 \mathrm{~m},-4 \mathrm{~m}$ and $-6.5 \mathrm{~m}$. Specially designed waling units were used to transmit the horizontal component of the anchor load to support the sheet piles against earth pressure. Heavy brackets welded to the sheet piles carried the vertical components of the anchors and also supported the walings during erection.

171. The vertical component from the anchors supplied a substantial proportion of the total stress in the sheet piles. The anchors at the top level were spaced at $5.5 \mathrm{~m}$ centres and the vertical component of each anchor was supported by a group of five sheet piles welded at the clutches. Each waling at the lower levels carried twice the load taken by the top waling and anchors were grouped in pairs which were also spaced at $5.5 \mathrm{~m}$ centres. To support the vertical loads from these levels pairs of Larssen box piles were incorporated into the sheet pile curtain to act as king piles at the anchor pair locations. The vertical loads taken by these box piles were high and great effort was made to ensure that they were firmly founded in bedrock. 
172. After drilling and grouting the anchors of each level, each anchor was tested to full load before excavation proceeded to the next level. The anchors were designed to resist the maximum anticipated active pressures at any stage of excavation. If left prestressed at the test load they would have exerted their full downward component whether or not the maximum anticipated active pressure developed. Since the active pressures used were calculated on a pessimistic basis it was decided to relax the stress after testing to $75 \%$ of the safe working load. This was judged to be adequate to hold the piling tight against the supported ground to prevent movement developing, without running the risk of excessive deflexion of the piling due to stretching of the anchor wire should the full active pressure be applied.

173. Since the piling did not penetrate far below the formation level, the primary excavation was arranged so that a berm was left to support the toes of the piles while the main section of the pumphouse floor was piled and concreted. The toes of the piles were then braced and strutted against the primary concrete so that the berm could be excavated and the outer perimeter of the concrete floor placed in short sections.

\section{Messrs Geddes, Sturrock and Kinder}

We are obliged to Mr Worth for his contribution from the contractor's viewpoint which adds greatly to the practical value of the Paper. The dock wall profile was determined having regard not only to the horizontal loads applied from the backfilling but also to the high vertical loads imposed by the cranes. The dock wall section with a sloping inside face was our preferred profile to deal with the present loading and possible future loading conditions. The overhanging cope provided a recess below which the dockside services could be conveniently installed. While the sand runs on the inside face of the dock were unsightly in the early life of the dock walls, they were quickly lost under the natural staining caused during the flooding of the dock. Since it was decided to backfill the whole length of the dock walls with rock fill, thereby allowing fairly free access for tidal and ground water, it was considered that excessive pumping would be required to deal with a drainage system behind the dock walls. The floor was considered to be rather more vulnerable to water pressure than the walls and economies were obtained by providing drainage arrangements under the dock floor.

175. Mr Sweetnam has given an interesting historical account of the ships and port facilities in Belfast and rightly emphasized the acceleration in the growth of ship dimensions which has demanded larger civil engineering structures. His interest, along with that of the other members of the Belfast Harbour Commissioners, was of great assistance in the development and construction of this project and is gratefully acknowledged.

176. Regarding the query raised by Mr Berry about the cement content of the mix, this was varied from the minimum specified of $285 \mathrm{~kg} / \mathrm{m}^{3}$ to above $300 \mathrm{~kg} / \mathrm{m}^{3}$. The cement content selected was rather more than the minimum for 'moderate' conditions stipulated in the Unified Code which appears to be suitable for the Belfast site. The water behind the dock walls was not particularly saline since it originated mainly from groundwater rather than the adjacent sea. Therefore there was no need to consider this water as salt water nor were the wetting or drying conditions considered to be exceptional. The strength requirements were adequately met and the use of the minimum cement content was generally maintained to keep shrinkage to a minimum and also from an economic point of view. The coarse grained cement and chemical nature of the cement produced in Northern Ireland appears to give one of the lowest heat conditions for normal cement in the UK. The use of higher cement content referred to was tried in the dock walls in an endeavour to overcome the sand run problem. In some panels this appeared to be effective, while in other panels it did not make any significant difference to the sand runs so it was agreed to revert to the minimum cement content.

177. The dock walls were designed as normal reinforced concrete elements. They 
were not designed in accordance with the water-retaining code having regard to the massive nature of these walls, which were also required to carry high vertical loads imposed by the cranes. However, careful attention was paid to bond lengths and cut-off points of the reinforcing bars and this aspect of the design was based on USA Codes which were more conservative in this respect than the UK Codes. Patent PVC ribbed water bars were attached externally to the back face of the dock wall joints and to the underside of the floor panel joints to help maintain the water seal as the concrete shrunk on curing. This shrinkage was sufficient to allow for the expansion which occurs in the concrete during warmer times of the year. Owing to the relative massive nature of the walls and floors the movement due to temperature changes appears minimal although a visual difference can be observed in the floor joints between summer and winter. The bitumen paint on each joint also provided a small additional expansion element but since no weeping or squeezing out of this bitumen has been noted, this indicates that expansion does not appear to be a major problem. In placing the cofferdam, the outer faces were tipped using relatively heavy sandstone fill obtained from an old quarry. However, having in mind the need to drive sheet piling along the centre of the cofferdam, the Contractor carefully placed a core of finer quarry debris material. Therefore there was no need to drive piles through heavy rockfill and no difficulty was experienced with this sheet piling. The cut-off formed was effective in providing a reasonable seal and although leakage was not entirely eliminated it could be controlled with nominal pumping.

178. Mr Tomlinson made a thorough study of the soil conditions and behaviour throughout the construction period and his observations are of great interest. Basically, it was considered that failure by a deep slip circle was remote by virtue of the fact that the clays increased in strength with depth. The temporary rockfill toe placed along the slope after partial dewatering served many purposes, such as adding to the stability immediately after final dewatering, forming a convenient access road and providing access for dealing with shallow surface' slips. The proposal to drive piles under the foundation of the wall was taken to eliminate extra excavation with the consequent danger of undercutting; the toe of the slope also provided a sound investment. A further bonus was gained since the piles proved convenient points of support for buttressing the concrete wall used as a back shutter for the wall foundations.

179. It was noted on site that vertical cracks formed in the 'sleech' when it dried out which allowed ingress of surface water which caused some instability in certain areas. While the view was formed that cracks in the boulder clay caused by earlier pile driving led to problems, it was noted that these piles greatly assisted in pinning the side slopes. Many minor slips were restricted from developing into large slips by single old timber piles which had been driven during the changing life of the Musgrave Channel.

180. We appreciate that a job of this magnitude depended on simplicity and effectiveness of detail to ensure adherence both to construction programme and to cost and, as Mr Land suggests, further information regarding detail would have been useful especially from the Contractor's viewpoint. The steeper batter in the Belfast wall shutter, compared with that of the Greenock dock, probably encouraged the development of sand runs. The height of the pour at Belfast was also appreciably higher than that at Greenock and the wall lift of some $10 \mathrm{~m}$ in height and containing about $250 \mathrm{~m}^{3}$ of concrete was placed in about six to eight hours. The steel shutter used was insulated on the outside to assist in developing the early strength of the concrete during the winter period but the problem of sand runs did not appear to follow any particular pattern in summer or winter. As explained earlier, increased cement contents did not make any significant difference and while a more cohesive mix would probably have helped, the local sand available was water-washed coming from Lough Neagh and so tended to be coarse. The sand runs should not be over-emphasized in importance in this industrial concrete where the surface finish suffers far more from 
damage caused by shipbuilding operations and dock flooding. The sand runs were only of superficial depth and did not impair the concrete structure in any way. It is suggested that for more architectural concrete finishes, poured in high lifts, a more cohesive mix would help, along with a slower pouring rate to avoid slumping of the mass of the concrete away from the shutter.

181. With regard to the head wall anchors, no significant loss or increase in load was observed in the period after initial stressing to the time when the final stress was applied to the anchors. Mr Ashford has given a full description of the techniques employed at the east roundhead in his contribution and has covered most of the points raised by $\mathrm{Mr}$ Land.

182. Since the dock gate was designed as a bridge spanning horizontally between the 'abutment' quoins, heavy bearing pressures were experienced. It was for this reason that machined castings were used on the quoins in an endeavour to achieve uniform reactions. The accuracy specified was $0.05 \mathrm{~mm}$ over a straight edge length of $2.5 \mathrm{~m}$, similar to that specified for the sill stones. The dock gate, designed so as to be reversed from time to time for maintenance purposes, was fabricated to a high degree of accuracy by Sir William Arrol and Co., Structural Steelwork Engineers. Initially, some slight leakage was experienced but after a short time the gate sealed and leakage became minimal:

183. Some 7000 steel bearing piles were driven using both fixed rigs running on rails along with more mobile equipment, generally a $38 \mathrm{RB}$ crane. The fixed rigs were used to drive forward raking piles whereas the mobile rigs could also be used to drive vertical or under raked piles should this be necessary owing to access problems. Initially, piles were driven using a drop hammer because this early piling was carried out close to a building housing a computer. Having determined that vibrations caused by the piling were no worse than those caused by a typist walking across the floor of the computer room, the piling equipment was changed and a Delmag D22 piling hammer was used.

184. In reply to Mr Baxter, some 1500 drain block units, each weighing about $4 \mathrm{t}$, were lifted by projecting lifting bars quite successfully without any breakage or incident. However, care was taken to ensure that the lift was vertical and carried out in a smooth manner.

185. The suggestion made by Mr Agar that a combined pumping and electrical system might have been possible for the east twin repair dock and the shipbuilding dock was not investigated. By the time the Building Dock was mooted, designs for pumping and services had been finalized for East Twin, but in any event the location purpose and capacity of the two docks were so dissimilar that a combined system would probably not have been feasible.

186. Mr Williams emphasizes that the launch draught of a big ship is much less than the laden draught of the ship in service and accordingly building docks can be much shallower than ship locks. This factor would make the construction of a dock probably faster than a lock for the equivalent size of ship. We consider that the main reason for the excellent construction times on the project was the overriding attention paid by both Contractors and Consultants to standardization and to simplicity of detail.

187. In reply to Mr Mordell's contribution, steel piles were selected not only for cost effectiveness in load carrying capacity but also in that they had the important characteristic of being capable of being driven effectively and positively through varying strata, including penetrating into the layers of weathered sandstone. They displaced the minimum amount of material which was important in view of the proximity of existing structures and the stability of the sides of the Musgrave Channel. The steel piles were also easy to adjust to accommodate the varying lengths required and the small cut-offs were welded together and used for the short $10 \mathrm{~m}$ piles below the dock wall. This gave rise to little waste of piling material and was an economic factor of some importance. A number of piles were tested to a $50 \%$ overload and 
the deflexions recorded were very similar to the elastic deflexions expected with end bearing piles. Since the piles were driven into relatively soft sandstone the set was recorded over the final $300 \mathrm{~mm}$, rather than sets taken over $3 \times 25 \mathrm{~mm}$, to ensure that piles were firmly driven. In short, the steel piles eliminated doubt and added accuracy and consistency to the planning, ordering and programming of the work.

188. We are grateful to Mr Cox for enlarging on the design of the dock gate and gratefully acknowledge the excellent work done by Sir William Arrol and Co. on the construction and installation. The thought given to the problem of preventing leakage at the lower corners has been justified and no leakage at these points has been apparent.

189. Many of the contributors, including Mr Craigmile, referred to experience of sand runs. Precautions which might be taken to eliminate them could include vertical or near-vertical faces if possible, timber rather than steel shuttering, precautions against over-vibration to avoid water runnels adjacent to the shutter, and a mix containing adequate cement. There appears to be no fundamental solution to the problem nor has the cause of sand runs really been isolated from the various techniques required to produce concrete. One difficulty on a job which moved so fast was that there was little time available to study and experiment with many of the interesting problems which arose as the work progressed.

190. We thank Mr Ashford for describing so fully the construction of the two roundheads, each with its particular problems to be overcome. The description of the temporary works at the east roundhead containing the pumphouse probably answers many of the questions posed by Mr Land on this particular cofferdam. After investigating many methods of constructing the east roundhead the decision taken by the Contractor to adopt an open cofferdam, using sheet piling supported by rock anchors, proved to be a good solution and without doubt assisted in maintaining this element of the job on programme.

191. We were pleased to have the contribution from Mr Kimber in which he briefly outlined the philosophy behind the whole shipbuilding dock project. The project started under his able guidance and he laid down and developed many of the parameters which were the backbone of the scheme. The close co-operation between the Shipbuilder, the Contractor and the Consulting Engineer ensured that all problems were shared, discussed and overcome in a manner acceptable to the final scheme and within the programme dates. The difficulties of continuing shipbuilding while such a major undertaking was in hand are not hard to understand but to start the building of a huge tanker in a part-completed dock at the same time called for both courage and faith. We gratefully acknowledge the help and forbearance shown by all members of Harland and Wolff at Queen's Island during this general upheaval which assisted in no small way in ensuring that the project was completed timeously.

\section{References}

3. Bertlin D. P. et al. Bombay dock expansion scheme: planning and design. Proc. Instn Civ. Engrs, 50, Dec., 401-417.

4. BertLIN D. P. and KIPPS K. O. Bombay dock expansion scheme: construction. Proc. Instn Civ. Engrs, 50, Dec., 419-433. 